\title{
“Or A TREATy OF THE United STATES": Treaties AND THE AliEN TORT STATUTE AfTER KIOBEL
}

\author{
By Geoffrey R. Watson*
}

The decision in Kiobel v. Royal Dutch Petroleum Co. ${ }^{1}$ left open a number of questions about the scope of the Alien Tort Statute (ATS). One such question is the extent to which Kiobel's holding on extraterritoriality applies to the oft-neglected final words of the ATS: "The district courts shall have original jurisdiction of any civil action by an alien for a tort only, committed in violation of the law of nations or a treaty of the United States." "What if one such treaty obliged the United States to provide a civil forum for litigation of human rights violations that occurred abroad and did not involve piracy?

Imagine, for example, a hypothetical treaty that obliged states parties not only to exercise universal criminal jurisdiction over accused torturers but also to provide a civil forum for torture victims who wish to sue their torturers in tort, regardless of where the tort occurred and regardless of the nationality of the parties. If the United States signed and ratified such a treaty, would the ATS apply to it? What if the treaty text went so far as to cite the ATS as an appropriate vehicle for implementation of the treaty obligation? Or what if the Senate, in giving advice and consent, expressed its view that the ATS was the appropriate vehicle for implementation of the treaty obligation? Even if the Senate declared that the treaty was otherwise non-self-executing, could its simultaneous declaration that the treaty was already implemented by the ATS have some bearing on the extraterritorial reach of the ATS?

The Supreme Court's opinion in Kiobel, like much other writing on the ATS, focuses on the ATS's reference to the "law of nations," which is understood to mean customary international law, or at least something other than treaty law. It is not surprising that the Supreme Court prefers to apply the framers' original understanding of the "law of nations" to ATS litigation; there are reasons to be skittish about incorporating modern norms of customary law into a statute adopted in 1789. As Curtis Bradley and others have observed, customary law is in tension with democratic norms: our Congress has almost no say in its development, and even the president has only a limited power to create or shape customary law given that the United States

\footnotetext{
* Professor of Law, The Catholic University of America.

${ }^{1}$ Kiobel v. Royal Dutch Petroleum Co., 133 S.Ct. 1659 (2013).

${ }^{2} 28$ U.S.C. $\$ 1350$ (emphasis added).
} 
is but one of almost two hundred contributors to the formation of such law. ${ }^{3}$ Moreover, customary law is difficult to ascertain and may not be a significant source of new international legal norms anyway. ${ }^{4}$

But the Court's opinion says little about the treaty clause of the ATS, and the functional arguments against extraterritorial application of the treaty clause are weaker. Treaties have less of a democracy problem than customary law has. Treaties are negotiated and signed under the authority of the president, a democratically elected official. The popularly elected Senate must give advice and consent to ratification.

The historical arguments for extraterritorial application of the treaty clause are also stronger than those pertaining to the "law of nations" clause. Consider Attorney General William Bradford's 1795 opinion on the ATS, in which he said that the ATS might cover tortious actions by Americans overseas that violated a treaty between the United States and Great Britain. ${ }^{5}$ The respondents in Kiobel distinguished the opinion on the grounds that it involved a treaty with extraterritorial effect. ${ }^{6}$ For their part, the petitioners and the solicitor general argued that the opinion meant the ATS had extraterritorial effect, even in cases not involving a treaty. ${ }^{7}$ Thus the Kiobel parties agreed on the proposition that the ATS might be an appropriate vehicle for a case involving a treaty with extraterritorial effect. ${ }^{8}$

The Kiobel Court did not take a clear position on these historical arguments. Its reaction to the Bradford opinion, for example, was somewhat cryptic:

Attorney General Bradford's opinion defies a definitive reading and we need not adopt one here. Whatever its precise meaning, it deals with U.S. citizens who, by participating in an attack taking place both on the high seas and on a foreign shore, violated a treaty between the United States and Great Britain. The opinion hardly suffices to counter the weighty concerns underlying the presumption against extraterritoriality. ${ }^{9}$

This passage did not unequivocally endorse the respondents' theory that the ATS covers a treaty with explicit extraterritorial reach, but it did not need to do so since Kiobel itself did not involve such a treaty. But does the last sentence quoted above mean that the Court would reject application of the ATS to a modern-day version of Bradford's case, even if that case involved a treaty of extraterritorial reach? Perhaps that situation is an example of what Justice Anthony

\footnotetext{
3 See, e.g., Curtis A. Bradley, The Costs of International Human Rights Litigation, 2 CHI. J. INT'L L. 457, 464-70 (2001).

${ }^{4}$ Cf. Sean D. Murphy, Book Review, 104 AJIL 697, 697 (2010) (noting that "it is actually rather difficult to identify a new norm of international law that has emerged purely as a matter of widespread state practice, at least in the form of what states actually do on the ground").

51 Op. Att'y Gen. 57, 58 (1795).

${ }^{6}$ See Supplemental Brief for Respondents at 28-30, Kiobel v. Royal Dutch Petroleum Co., 133 S.Ct. 1659 (2013) (No. 10-1491), cited in Kiobel, 133 S.Ct. at 1667-68. Briefs filed in Kiobel are available online at http:// cja.org/section.php?id_509.

7 Petitioners' Supplemental Opening Brief at 13-15, Kiobel v. Royal Dutch Petroleum Co., 133 S.Ct. 1659 (2013) (No. 10-1491); Supplemental Brief for the United States as Amicus Curiae in Partial Support of Affirmance at 10, Kiobel v. Royal Dutch Petroleum Co., 133 S.Ct. 1659 (2013) (No. 10-1491).

${ }^{8}$ That said, the framers of the ATS probably did not intend the statute to cover executive agreements. Executive agreements did develop in early American practice, but the term treaty was usually reserved for Article II treaties. See Bradford R. Clark, Domesticating Sole Executive Agreements, 93 VA. L. REV. 1573, 1581-84 (2007).

${ }^{9}$ Kiobel, 133 S.Ct. at 1668.
} 
Kennedy, the fifth vote on extraterritoriality, had in mind when he mentioned cases not covered "by the reasoning and holding of today's case." 10

None of the main participants in Kiobel - petitioners, respondents, the solicitor general, or the Court itself - took the position that the phrase "treaty of the United States" excludes treaties ratified after 1789 . Scholarly commentators generally seem to assume that the ATS covers both pre-enactment and post-enactment treaties. For example, some debate exists about which treaty was at issue in the Bradford opinion: the 1783 Treaty of Paris, or the 1794 Jay Treaty? Thomas Lee argues that Bradford meant the Jay Treaty, which has the more "on-point" antineutrality rule. ${ }^{11}$ Bradley and Ishai Mooreville argue that Bradford probably meant the Treaty of Paris because the Jay Treaty had been signed but not yet ratified in $1795 .{ }^{12}$ Whatever the merits of this historical argument, ${ }^{13}$ no one has suggested that the extraterritorial reach of the ATS's treaty clause depends on when the treaty entered into force. ${ }^{14}$ In other areas of U.S. statutory law, a reference to a "treaty" ordinarily means treaties that predate the statute as well as treaties that postdate the statute, unless otherwise indicated. ${ }^{15}$ Likewise, a plurality in the Supreme Court's ruling in Reid v. Covert held that the Supremacy Clause covers all treaties, regardless of whether they predate or postdate the Constitution. ${ }^{16}$

Thus, whatever policy and historical considerations justify limiting the "law of nations" to the categories that the Court has sketched in Sosa and Kiobel, those considerations do not justify

${ }^{10}$ Id. at 1669 (Kennedy, J., concurring).

11 Thomas H. Lee, The Safe-Conduct Theory of the Alien Tort Statute, 106 COLUM. L. REV. 830, 891-92 \& n.312 (2006) (citing Definitive Treaty of Peace, U.S.-Gr. Brit., Art. VII, Sept. 3, 1783, 8 Stat. 80 [hereinafter Treaty of Paris]; Treaty of Amity, Commerce and Navigation, U.S.-Gr. Brit., Art. XXI, Nov. 19, 1794, 8 Stat. 116 [hereinafter Jay Treaty]).

${ }^{12}$ Curtis A. Bradley, Attorney General Bradford's Opinion and the Alien Tort Statute, 106 AJIL 509, $521 \mathrm{n} .82$ (2012); Ishai Mooreville, A Question of Sovereignty: The History Behind Attorney General Bradford's 1795 Opinion on the Alien Tort Statute, 40 SYRACUSE J. INT'L L. \& COM. 217 (2013).

${ }^{13}$ Bradford issued his opinion on July 6, 1795, before the Jay Treaty entered into force, but just two weeks after the Senate gave conditional advice and consent to the treaty. The safer conclusion is that Bradford was thinking of the 1783 Treaty of Paris, not the Jay Treaty, especially as ratification of the Jay Treaty was controversial. At that time, of course, there was no Vienna Convention on the Law of Treaties, May 23, 1969, 1155 UNTS 33, whose Article 18 obliges states to "refrain from acts which would defeat the object and purpose" of signed but unratified treaties. Moreover, Bradford was undoubtedly conscious of the constitutional requirement of ratification. Cf. Curtis A. Bradley, Unratified Treaties, Domestic Politics, and the U.S. Constitution, 48 HARV. INT'L L.J. 307, 314 (2007) (noting that " $[\mathrm{t}]$ he United States repeatedly had to remind other countries during the nineteenth century that its signature did not constitute a promise of ratification" (citing J. MERVYN JONES, FULL POWERS AND RATIFICATION 76-77 (1946))). Bradford presumably understood the difference between Senate advice and consent and actual ratification by the president — a distinction sometimes lost on modern Americans. Still, the timing of Bradford's opinion creates some uncertainty. Moreover, the neutrality provision in the Treaty of Paris is less detailed than its counterpart in the Jay Treaty, which might have seemed more like the applicable lex specialis to Bradford. Article XXI of the Jay Treaty, for example, states that "the laws against all such offences and aggressions shall be punctually executed"; the Treaty of Paris contains no such provision.

${ }^{14}$ Cf., e.g., Bradley, supra note 12, at $521 \mathrm{n} .82$ ("In any event, the issue [of which treaty Bradford had in mind] is not material to this essay.").

15 See, e.g., 18 U.S.C. $\$ 3184$ (conditioning international extradition on the existence of a "treaty or convention for extradition”); cf. OSS Nokalva, Inc. v. Eur. Space Agency, 617 F.3d 756, 761-66 (3d Cir. 2010) (holding that the International Organizations Immunities Act of 1945 (IOIA), 28 U.S.C. \$288, incorporates later-enacted provisions of the Foreign Sovereign Immunities Act); Atkinson v. Inter-American Dev. Bank, 156 F.3d 1335 (D.C. Cir. 1998) (rejecting this view). The IOIA cases involve a later statute, not a later treaty, and, in any case, the Nokalva court has the better argument. See 2B SUTHERLAND STATUTORY CONSTRUCTION \$51.08, at 192 (Norman J. Singer ed., 5th ed. 1992) ("A statute which refers to a subject generally adopts the law on the subject as of the time the law is enacted. This will include all the amendments and modifications of the law subsequent to the time the reference statute was enacted."), quoted in Nokalva, 617 F.3d at 763.

16 See Reid v. Covert, 354 U.S. 1, 17-18 (1957) (plurality opinion). 
limiting "treaties" either to those treaties that existed in 1789 or to the types of treaties that existed in 1789. The framers of the ATS, like the framers of the Constitution, understood that the United States would enter into new and different treaties as the Republic evolved. They understood that the United States has far more control over "treaties of the United States" than over the brooding omnipresence that is the "law of nations." 17 They understood that the United States can pick and choose its treaties, whereas it cannot pick and choose its own customary law.

So if functional and historical concerns do not preclude extraterritorial application of the treaty clause of the ATS, does the self-executing treaty doctrine stand in the way? The Court's opinion in Sosa says it does. The Sosa Court dismissed the plaintiff's reliance on the International Covenant on Civil and Political Rights in one sentence: "And, although the Covenant does bind the United States as a matter of international law, the United States ratified the Covenant on the express understanding that it was not self-executing and so did not itself create obligations enforceable in the federal courts." 18

The Court's invocation of the self-executing treaty doctrine in Sosa was mistaken. The doctrine does not mean that a non-self-executing treaty can never help create legal obligations in domestic courts - only that the treaty does not create such obligations by its own force. The obvious case is a non-self-executing treaty that is followed by congressional implementing legislation. In such a case, the treaty itself does not have direct force of law, but the statute implementing it does. ${ }^{19}$

Moreover, a non-self-executing treaty may be implemented by preexisting legislation. Oona Hathaway, Sabria McElroy, and Sara Aronchick Solow cite two prominent examples, section 1983 and the federal habeas corpus statute, both of which have been used to enforce treaty rights. ${ }^{20}$ Consider also extradition law — a body of law that, like the ATS and the Torture Victim Protection Act (TVPA), helps ensure that the United States does not become a "safe haven" for wrongdoers. ${ }^{21}$ Extradition treaties work in tandem with the preexisting federal extradition statute, which serves as preexisting implementing legislation. ${ }^{22}$ U.S. domestic courts have routinely enforced extradition treaties even though, until recently, Senate resolutions of advice and consent did not usually include a statement that an extradition treaty was self-executing. ${ }^{23}$

\footnotetext{
${ }^{17}$ Cf. S. Pac. Co. v. Jensen, 244 U.S. 205, 222 (1917) (Holmes, J., dissenting) ("The common law is not a brooding omnipresence in the sky but the articulate voice of some sovereign or quasi sovereign that can be identified ....").

${ }^{18}$ Sosa v. Alvarez-Machain, 542 U.S. 692, 735 (2004); cf. Bradley, supra note 3, at 464 (asserting that ATS plaintiffs avoid the treaty clause "[b] ecause of the limited way in which the President and Senate have consented to human rights treaties").

19 See Oona A. Hathaway, Sabria McElroy \& Sara Aronchick Solow, International Law at Home: Enforcing Treaties in U.S. Courts, 37 YALE J. INT'L L. 51, 77-78 (2012) (citing congressional legislation implementing non-selfexecuting treaties such as the Torture Victim Protection Act, the Hague Child Abduction Convention, and the Chemical Weapons Convention).

${ }^{20}$ Id. at $78-83$.

${ }^{21}$ Cf. S. REP. No. 102-249, at 3-4 (1991) (asserting that the Torture Victim Protection Act would help ensure that "torturers and death squads will no longer have a safe haven in the United States"), quoted in Kiobel v. Royal Dutch Petroleum Co., 133 S.Ct. 1659, 1677 (2013) (Breyer, J., concurring).

22 See 18 U.S.C. $\$ 3184$ (requiring a “treaty” for extradition).

${ }^{23}$ Until 2008, such resolutions typically contained no references to the self-executing treaty doctrine, though they always included a Bricker Amendment. See, e.g., 148 CONG. REC. S11,057 (daily ed. Nov. 14, 2002) (extradition treaty with Peru); 146 CONG. REC. S23,086 (daily ed. Oct. 18, 2000) (South Africa \& Sri Lanka); id. at
} 
After Medellin v. Texas ${ }^{24}$ raised doubts about the self-executing character of such treaties, the Senate changed its practice and began to include explicit statements that such treaties are self-executing in the resolution of advice and consent as part of a broader undertaking "to address uncertainty regarding the self-executing character of some U.S. treaties." 25

Through all of these developments, U.S. federal courts have continued to enforce extradition treaties, regardless of whether they are self-executing, because they are implemented by U.S. law. Courts should adopt the same approach to human rights treaties and the ATS. Hathaway and her coauthors are absolutely right when they suggest that " $\mathrm{t}$ ] he Alien Tort Claims Act ... might be thought to be an additional mechanism for indirect enforcement of a treaty," along with other mechanisms, such as the federal habeas statute, section 1983, and the TVPA. ${ }^{26}$

In a perfect world, Congress would step in and clarify the scope of the ATS. Failing that, perhaps the Senate might consider extending its new (and commendable) practice of stating explicitly when a treaty is self-executing. The best practice-long sought by human rights activists - would be for the Senate to declare that future human rights treaties are selfexecuting, at least insofar as their self-executing status would not violate constitutional norms. That declaration would get around the specious objection posed by Sosa, but it may be too much to ask.

Perhaps, instead, the Senate might consider a more modest variation on its new declaration practice. Rather than declare a human rights treaty to be self-executing, the Senate might say that " $\mathrm{t}]$ he Senate declares that this treaty is a 'treaty of the United States' for the purposes of the Alien Tort Statute. Furthermore, the Senate declares that the Alien Tort Statute would be an appropriate vehicle for civil enforcement of the legal obligations in this treaty." (For that matter, the president could do so in the treaty text or when transmitting the treaty text to Congress.) If the treaty text is unclear about its extraterritorial reach, the Senate could express itself on that question as well. If the Senate determines that it would be inadvisable for the ATS to apply to a particular treaty, then the Senate should say so.

The Senate's declarations on self-executing status already have domestic legal consequences. ${ }^{27}$ So should its declarations on other ways in which a treaty interacts with existing U.S. law. Like a declaration on self-executing status, such a declaration should not be dispositive, but it should be entitled to a certain amount of weight.

The ATS is, if you will, pre-implementing legislation-just like the extradition statute, section 1983, and the federal habeas statute. The ATS establishes jurisdiction over a civil claim for a tort in violation of a "treaty of the United States," not just a "self-executing treaty of the United States." It should be interpreted so that it means what it says.

S23,085 (Belize, Paraguay); 145 CONG. REC. S28110 (daily ed. Nov. 3, 1999) (Korea). The Senate Foreign Relations Committee did sometimes express the general view that such treaties were self-executing, see, e.g., SEN. EXEC. RPT. 106-26, at III (2000) (noting that "the legal procedures for extradition are governed by both federal statutes and self-executing treaties"), but such statements were not included in the resolution voted on by the full Senate.

${ }^{24}$ Medellín v. Texas, 552 U.S. 491 (2008).

${ }^{25}$ John R. Crook, Contemporary Practice of the United States Relating to International Law, 104 AJIL 100, 100 (2010) (Senate Foreign Relations Committee documenting self-executing character of new extradition treaties).

${ }^{26}$ Hathaway, McElroy \& Aronchick Solow, supra note 19, at 77 n.157.

27 See Sosa v. Alvarez-Machain, 542 U.S. 692, 745 (2004); 1 RESTATEMENT (THIRD) OF THE FOREIGN RELATIONS LAW OF THE UNITED STATES $\$ 111(3)-(4)(1987)$. 